\title{
KESESUAIAN KOLESTEROL LDL HASIL PERHITUNGAN SEJUMLAH FORMULA DENGAN KOLESTEROL LDL DIREK METODE ENZIMATIK
}

\author{
Dona Liazarti', May Valzon ${ }^{2}$ \\ ${ }^{1}$ Fakultas Kedokteran dan Ilmu Kesehatan, Universitas Abdurrab Pekanbaru \\ Email:donaliazarti@gmail.com \\ ${ }^{2}$ Fakultas Kedokteran dan Ilmu Kesehatan, Universitas Abdurrab Pekanbaru \\ Email: may.valzon@univrab.ac.id
}

Masuk: 21-07-2021, revisi: 04-06-2021, diterima untuk diterbitkan: 22-08-2021

\begin{abstract}
ABSTRAK
Peningkatan kadar kolesterol merupakan penyebab utama penyakit jantung koroner. Hasil pemeriksaan kadar LDL serum harus tepat dan akurat, namun pemeriksaan kadar LDL secara langsung (LDL-Direk) cukup mahal untuk dilakukan di tempat dengan fasilitas terbatas sehingga dilakukan berbagai percobaan untuk mendapatkan formula perhitungan LDL (LDL-Cal) yang lebih tepat dibandingkan formula yang telah umum digunakan yaitu formula Friedewald. Penelitian ini bertujuan untuk mengetahui kesesuaian antara kolesterol LDL hasil perhitungan sejumlah formula dengan kolesterol LDL direk sehingga diperoleh formula perhitungan terbaik untuk dapat diterapkan di laboratorium RSUD Lubuk Sikaping. Penelitian ini dilakukan terhadap 75 orang pasien yang melakukan pemeriksaan profil lipid lengkap ke Laboratorium RSUD Lubuk Sikaping. yang memenuhi kriteria inklusi. Pemeriksaan kolesterol total, HDL, LDL dan trigliserida dilakukan dengan metode enzimatik pada alat kimia klinik otomatis. Untuk kolesterol LDL juga dihitung dengan beberapa rumus yaitu formula Friedelwald (TC-(TG/5)-HDL). formula Chen (90\%nonHDLC-10\% TG), formula Anandaraja (0.9 TC- (0.9 TG/5)-28), formula Puavilai (TCHDLC-TG/6), formula Vujovic (TC-HDLC-TG/3), dan formula Cordova (3/4 (TC-HDLC). Bland \& Altman plot digunakan untuk membandingkan antara kadar kolesterol LDL hasil hitung masing-masing formula dengan LDL direk. Rerata kadar LDL (mg/dl) berturut-turut adalah 136,41 (35,92); 116,64 (32,72); 117,03 (30,83); 121,95 (32,79); 121,83 (33,23); 96,84 (32,47); 109,97 (28,24) untuk LDL-Direk, Friedelwald, Chen, Anandaraja, Puavilai, Vujovic, dan Cordova. Berdasarkan Bland \& Altman Plot, perhitungan kolesterol LDL Formula Chen memiliki kesesuaian paling baik dengan LDL-Direk dengan selisih rerata 19,3867 \pm 19,0489 mg/dl pada kadar trigliserida < $400 \mathrm{mg} / \mathrm{dl}$, sehingga dapat diterapkan di RSUD Lubuk Sikaping dengan fasilitas yang terbatas.
\end{abstract}

Kata Kunci: Kolesterol LDL; LDL-Direk; LDL-Cal

\begin{abstract}
Increased cholesterol levels are the main cause of coronary heart disease. The results of examining LDL must be precise and accurate, but direct LDL examination ( $L D L$-Direct) is quite expensive to do in a place with limited facilities so various experiments are carried out to get LDL formula (LDL-Cal) that is appropriate than formula commonly used, Friedewald formula. The aimed of this study was to determine the correlation between LDL cholesterol from calculation a number formulas with direct LDL cholesterol in order to obtain the best formula to be applied in laboratory of Lubuk Sikaping Hospital. This research was conducted on 75 patients who did lipid profile examination in laboratory of Lubuk Sikaping Hospital, who meet the inclusion criteria. Examination of total cholesterol, HDL, LDL and triglycerides were carried out by enzymatic methods on clinical chemistry analyzer. LDL cholesterol also calculated by several formulas namely Friedelwald formula (TC- (TG/5) -HDL), Chen formula (90\% nonHDLC-10\% TG), Anandaraja formula (0.9 TC- (0.9 TG/5) -28), Puavilai formula (TC-HDLC-TG/6), Vujovic formula (TC-HDLC-TG/3), and Cordova formula (3/4 (TC-HDLC.) Bland \& Altman plot was used to compare the calculated LDL cholesterol level of each formula with the direct LDL. The mean LDL levels were 136.41 (35.92); 116.64 (32.72); 117.03 (30.83); 121.95 (32.79); 121.83 (33.23); 96.84 (32.47); 109.97 (28.24) for Direct, Friedelwald, Chen, Anandaraja, Puavilai, Vujovic, and Cordova respectively. Based on the Bland \& Altman Plot, the calculation of LDL cholesterol from the Chen formula has the best compatibility with LDL-Direk with the
\end{abstract}


mean difference of $19.3867 \pm 19.0489 \mathrm{mg} / \mathrm{dl}$ at triglyceride levels $<400 \mathrm{mg} / \mathrm{dl}$, so it can be applied at RSUD Lubuk Sikaping with limited facilities.

Keywords: LDL Cholesterol; LDL-Direct; LDL-Cal

\section{PENDAHULUAN}

\section{Latar Belakang}

Sejumlah penelitian menunjukkan bahwa peningkatan kadar kolesterol merupakan penyebab utama penyakit jantung koroner. Hal ini didukung oleh sejumlah uji klinik yang menunjukkan bahwa terapi menurunkan kadar kolesterol LDL akan mengurangi risiko penyakit jantung koroner. Kadar kolesterol LDL yang dianggap optimal adalah $<100 \mathrm{mg} / \mathrm{dl}$. Pada Adult Treatment Panel III (ATP III) yang dikeluarkan oleh NCEP menganjurkan terapi yang lebih intensif untuk menurunkan kadar kolesterol LDL pada kelompok tertentu (Cholesterol \& Program, 2001).

Hasil pemeriksaan kadar LDL serum merupakan dasar untuk memulai pengobatan dan stratifikasi risiko pasien sehingga hasil pemeriksaan tersebut harus tepat dan akurat. Baku emas pemeriksaan kolesterol LDL adalah kuantifikasi beta/ $\beta$ (ultrasentrifugasi-presipitasi), namun tidak tepat untuk pemeriksaan rutin karena biayanya mahal, pengerjaan yang sulit, membutuhkan volume sampel yang banyak serta waktu yang lama. Metode ini hanya digunakan pada laboratorium khusus penelitian. Berikutnya dikembangkan pemeriksaan kadar LDL (LDL-Direk) dengan metode enzimatik "homogenous", tetapi karena biayanya yang masih cukup mahal, pemeriksaan ini dilakukan secara terbatas oleh laboratorium terutama di negara berkembang (Krishnaveni \& Gowda, 2015).

Dalam praktek sehari-hari, kadar LDL lebih banyak diperoleh dengan perhitungan (LDL-Cal) dan formula yang sering digunakan adalah Friedelwald (TC-(TG/5)-HDL). Formula ini memiliki keterbatasan yaitu tidak memberikan hasil perhitungan yang tepat pada sampel pasien yang tidak berpuasa dan atau kadar trigliserida > $400 \mathrm{mg} / \mathrm{dl}$ (Krishnaveni \& Gowda, 2015). Penelitian Martin et al., (2013) menunjukkan formula Friedelwald cenderung menghitung kolesterol LDL lebih rendah daripada yang terukur langsung (LDL-direk) terutama pada kadar trigliserida $\geq 150$ mg/dl. Hal ini sesuai dengan penelitian Fawwad et al., (2016) pada populasi di Pakistan. Berdasarkan hal tersebut, dilakukan penelitian untuk memperoleh formula perhitungan yang lain. Sejumlah formula yang digunakan untuk menghitung kadar LDL di antaranya formula Chen (90\%nonHDLC-10\% TG), formula Anandaraja (0,9 TC- (0,9 TG/5)-28), formula Puavilai (TCHDLC-TG/6), formula Vujovic (TC-HDLC-TG/3), dan formula Cordova (3/4 (TC-HDLC) (Dansethakul et al., 2015).

Hasil penelitian yang ditemukan Dansethakul et al., (2015) menunjukkan koefisien korelasi antara LDL-Direk dengan LDL-Cal masing-masing formula secara berurutan untuk Friedelwald, Anandaraja, Puavilai, Chen, Vujovic dan de Cordova adalah 0,954; 0,898; 0,970; 0,824; 0,954; dan 0,785 dengan nilai korelasi tertinggi untuk formula Puavilai. Hasil penelitian yang berbeda ditunjukkan oleh Krishnaveni \& Gowda (2015) yaitu formula Friedelwald memiliki korelasi yang baik dengan berbagai kadar trigliserida antara 200-400 mg/dl sedangkan formula Anandaraja memiliki korelasi yang lebih baik pada kadar trigliserida $<100 \mathrm{mg} / \mathrm{dl}$. Penelitian Rim et al., (2016) di Seoul, Korea yang melakukan analisis dengan Bland \& Altman Plot mendapatkan bahwa kolesterol LDL hasil hitung formula Chen memiliki selisih terkecil dibandingkan dengan ketiga formula lainnya yaitu formula Cordova, formula Anandaraja dan formula Friedewald. 
Klinisi perlu mengetahui kadar kolesterol LDL karena menjadi target utama terapi terutama dalam pencegahan penyakit jantung koroner. Laboratorium harus mampu memberikan hasil pemeriksaan kolesterol LDL yang valid. Pemeriksaan kolesterol LDL direk dengan metode enzimatik dapat menjadi acuan tetapi membutuhkan biaya yang cukup mahal sehingga pemeriksaan kolesterol menggunakan perhitungan rumus (formula Friedelwald) lebih umum digunakan termasuk di laboratorium RSUD Lubuk Sikaping, namun memberikan hasil yang bervariasi terutama ketika kadar trigliserida di atas $400 \mathrm{mg} / \mathrm{dl}$. Berbagai penelitian yang membandingkan sejumlah formula di beberapa populasi juga memberikan hasil yang bervariasi.

\section{Rumusan Masalah}

Berdasarkan latar belakang di atas, peneliti tertarik untuk mengetahui kesesuaian antara kolesterol LDL hasil perhitungan sejumlah formula dengan kolesterol LDL direk sehingga diperoleh formula perhitungan terbaik untuk dapat diterapkan di laboratorium RSUD Lubuk Sikaping.

\section{METODE PENELITIAN}

Sampel penelitian yang diambil adalah pasien yang melakukan pemeriksaan profil lipid lengkap (kolesterol total, kolesterol LDL, kolesterol HDL, trigliserida) ke Laboratorium RSUD Lubuk Sikaping yang memenuhi kriteria inklusi. Penelitian dilakukan pada bulan Februari sampai Mei 2020. Kriteria inklusi di antaranya usia > 18 tahun dan bersedia ikut penelitian (informed concent). Kriteria eksklusi adalah pasien yang tidak berpuasa 10-12 jam.

Bahan pemeriksaan dalam penelitian ini adalah darah vena yang ditampung dalam vacutainer tanpa antikoagulan dan dibiarkan pada suhu ruang selama 30 menit sampai satu jam sampai terbentuk bekuan. Sampel kemudian disentrifus dengan kecepatan $3500 \mathrm{rpm}$ selama 15 menit untuk mendapatkan serum sebagai spesimen pemeriksaan profil lipid. Semua analit (kolesterol total, HDL, LDL dan trigliserida) diperiksa dengan metode enzimatik pada alat kimia klinik otomatis Cobas C111. Untuk kolesterol LDL, selain diperiksa dengan alat juga dihitung (LDLCal) dengan beberapa rumus yaitu formula Friedelwald (TC-(TG/5)-HDL). formula Chen (90\%nonHDLC-10\% TG), formula Anandaraja (0.9 TC- (0.9 TG/5)-28), formula Puavilai (TCHDLC-TG/6), formula Vujovic (TC-HDLC-TG/3), dan formula Cordova (3/4 (TC-HDLC).

Analisis univariat dilakukan pada LDL-Direk, LDL-Cal formula Friedelwald, LDL-Cal formula Chen, LDL-Cal formula Anandaraja, LDL-Cal formula Puavilai, LDL-Cal formula Vujovic, dan LDL-Cal formula Cordova untuk menentukan rerata serta standar deviasi jika distribusi normal dan median serta interquartile range (IQR) jika distribusi tidak normal.

Bland \& Altman plot digunakan untuk membandingkan antara kadar kolesterol LDL hasil hitung masing-masing formula dengan LDL direk. Metode ini digunakan untuk mengetahui hubungan selisih antar tehnik pengukuran kolesterol LDL tersebut dengan rata-ratanya, selain itu untuk mengetahui outliers (pencilan, yaitu nilai pengamatan yang berbeda dengan pengamatan yang lain). Bland \& Altman plot dilakukan antara:

a. LDL-Cal formula Friedelwald dengan LDL-Direk

b. LDL-Cal formula Anandaraja dengan LDL-Direk

c. LDL-Cal formula Puavilai dengan LDL-Direk

d. LDL-Cal formula Chen dengan LDL-Direk

e. LDL-Cal formula Vujovic dengan LDL-Direk

f. LDL-Cal formula Cordova dengan LDL-Direk 


\section{HASIL DAN PEMBAHASAN}

Penelitian ini dilakukan terhadap 75 orang pasien yang melakukan pemeriksaan profil lipid lengkap ke Laboratorium RSUD Lubuk Sikaping. Karakteristik dasar subjek penelitian dapat dilihat pada Tabel 1.

Tabel 1. Karakteristik Subjek Penelitian

\begin{tabular}{lccr}
\hline & $\mathrm{n}(\%)$ & Rentang & Rerata (SD) \\
\hline Umur (tahun) & & $18-83$ & $58 \pm 12,45$ \\
Jenis kelamin & & & \\
$>$ Laki-laki & $38(51)$ & & \\
$>$ Perempuan & $37(49)$ & & \\
\hline
\end{tabular}

Tabel di atas menunjukkan bahwa rerata usia subjek penelitian adalah 58 tahun dengan didominasi oleh pria. Pemeriksaan laboratorium yang dilakukan dalam penelitian ini adalah kolesterol total, kolesterol LDL-Direk, kolesterol HDL, dan trigliserida. Pemeriksaan kolesterol LDL-Direk adalah pemeriksaan kolesterol LDL dengan mengukur kadar LDL langsung di dalam sampel darah subjek penelitian. Kolesterol LDL juga dihitung berdasarkan enam formula (LDLCal) yaitu formula Friedelwald, Chen, Anandaraja, Puavilai, Vujovic, dan Cordova. Hasil pemeriksaan profil lipid subjek penelitian tampak pada Tabel 2.

Tabel 2. Hasil Pemeriksaan Profil Lipid Subjek Penelitian

\begin{tabular}{|c|c|c|c|c|}
\hline \multirow{2}{*}{ Pemeriksaan } & & \multicolumn{2}{|c|}{ Rentang } & \multirow{2}{*}{$\begin{array}{l}\text { Rerata } \\
\text { (SD) }\end{array}$} \\
\hline & & Minimal & Maksimal & \\
\hline Kolesterol total & & 105 & 273 & $196,40(39,87)$ \\
\hline Kolesterrol HDL & & 10 & 105 & $49,87(18,07)$ \\
\hline Trigliserida & & 53 & 347 & $149,12(70,62)$ \\
\hline \multicolumn{5}{|l|}{ Kolesterol LDL } \\
\hline - $\quad$ Direk & & 66 & 216 & $136,41(35,92)$ \\
\hline \multirow[t]{6}{*}{ - $\quad$ Hitung (Cal) } & Formula Friedelwald & 35 & 197 & $116,64(32,72)$ \\
\hline & Formula Chen & 49 & 191 & $117,03(30,83)$ \\
\hline & Formula Anandaraja & 46 & 187 & $121,95(32,79)$ \\
\hline & Formula Puavilai & 42 & 203 & $121,83(33,23)$ \\
\hline & Formula Vujovic & 7 & 173 & $96,84(32,47)$ \\
\hline & Formula DeCordova & 56 & 174 & $109,97(28,24)$ \\
\hline
\end{tabular}

Tabel 2 menunjukkan rerata nilai kolesterol total, kolesterol HDL, dan trigliserida berturut-turut adalah 196,40 (39,87); 49,87 (18,07); dan 149,12 (70,62). Rerata kadar kolesterol LDL berturutturut adalah 136,41 (35,92); 116,64 (32,72); 117,03 (30,83); 121,95 (32,79); 121,83 (33,23); 96,84 (32,47); 109,97 (28,24) untuk LDL-Direk, Friedelwald, Chen, Anandaraja, Puavilai, Vujovic, dan Cordova. Hasil pemeriksaan kolesterol LDL-Direk dengan masing-masing formula LDL-Cal dihitung nilai selisih, rerata dan batas rentang kesesuaian seperti tampak pada Tabel 3. Grafik yang menunjukkan Bland \& Altman Plot dan rentang kesesuaian masing-masing formula tampak pada Gambar 1. 
Tabel 3. Nilai Selisih, Rerata dan Batas Rentang Kesesuaian antara Kadar Kolesterol Direk dengan Masing-Masing Kadar Kolesterol Hasil Perhitungan dari Enam Formula

\begin{tabular}{lcccc}
\hline \multirow{2}{*}{ Variabel } & \multicolumn{3}{c}{ Hasil perhitungan } \\
\cline { 2 - 5 } & $\begin{array}{c}\text { Selisih } \\
\text { (Difference) }\end{array}$ & $\begin{array}{c}\text { Rerata } \\
\text { (Mean) } \\
\mathrm{mg} / \mathrm{dl}\end{array}$ & $\begin{array}{c}\text { Batas bawah } \\
\text { rentang kesesuaian } \\
(-1,96 S D)\end{array}$ & $\begin{array}{c}\text { Batas atas } \\
\text { rentang kesesuaian } \\
(+1,96 S D)\end{array}$ \\
\hline Direk-Friedelwald (1) & 20,8868 & 19,7733 & $-21,1648$ & 60,7114 \\
Direk-Anandaraja (2) & 22,4634 & 14,4667 & $-29,5615$ & 58,4949 \\
Direk-Puavilai (3) & 20,1629 & 14,5867 & $-24,9326$ & 54,1060 \\
Direk-Chen (4) & 19,0489 & 19,3867 & $-17,9492$ & 56,7226 \\
Direk-Vujovic (5) & 25,8097 & 39,5733 & $-11,0137$ & 90,1603 \\
Direk-Cordova (6) & 19,2032 & 26,4400 & $-11,1983$ & 64,0783 \\
\hline
\end{tabular}
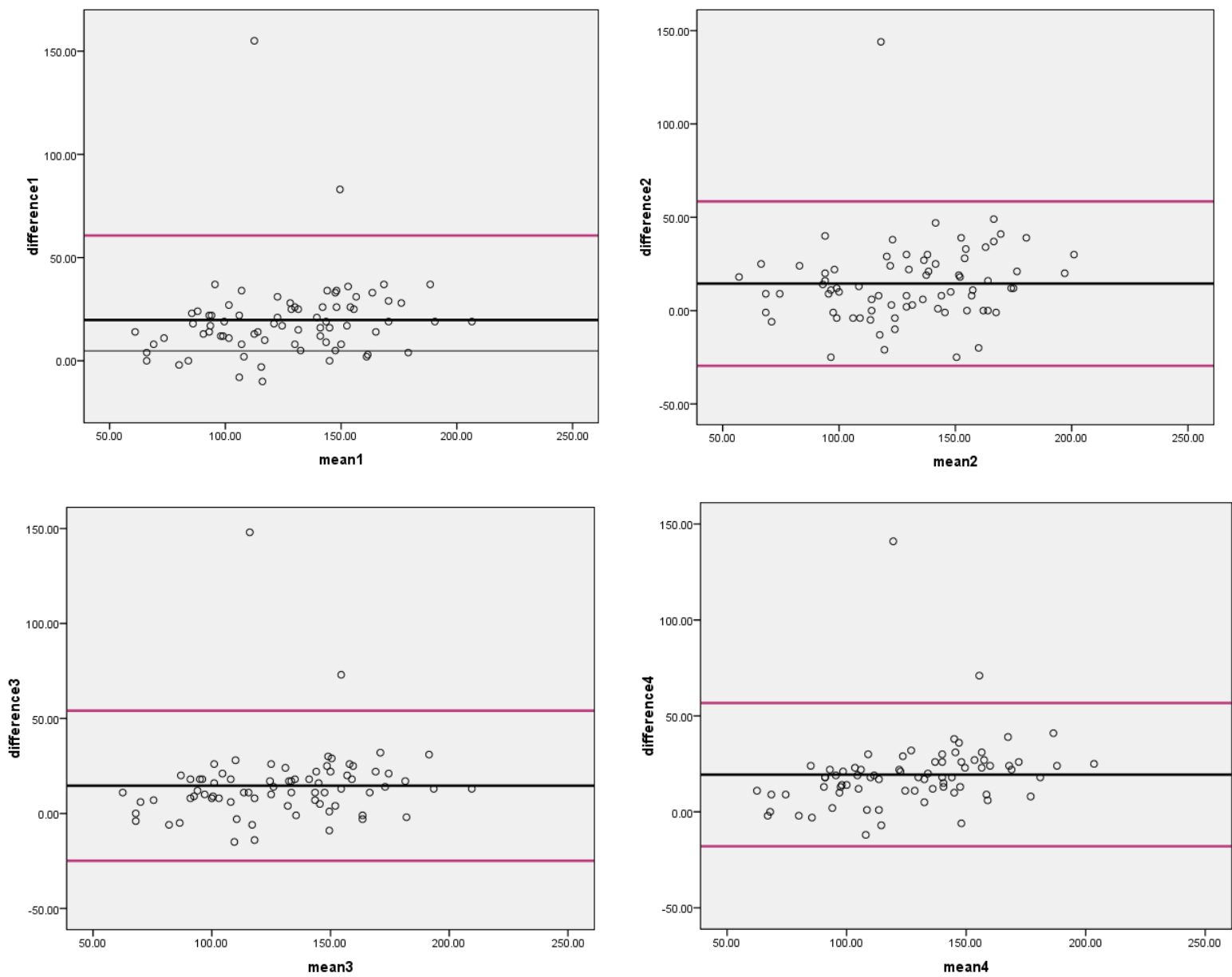

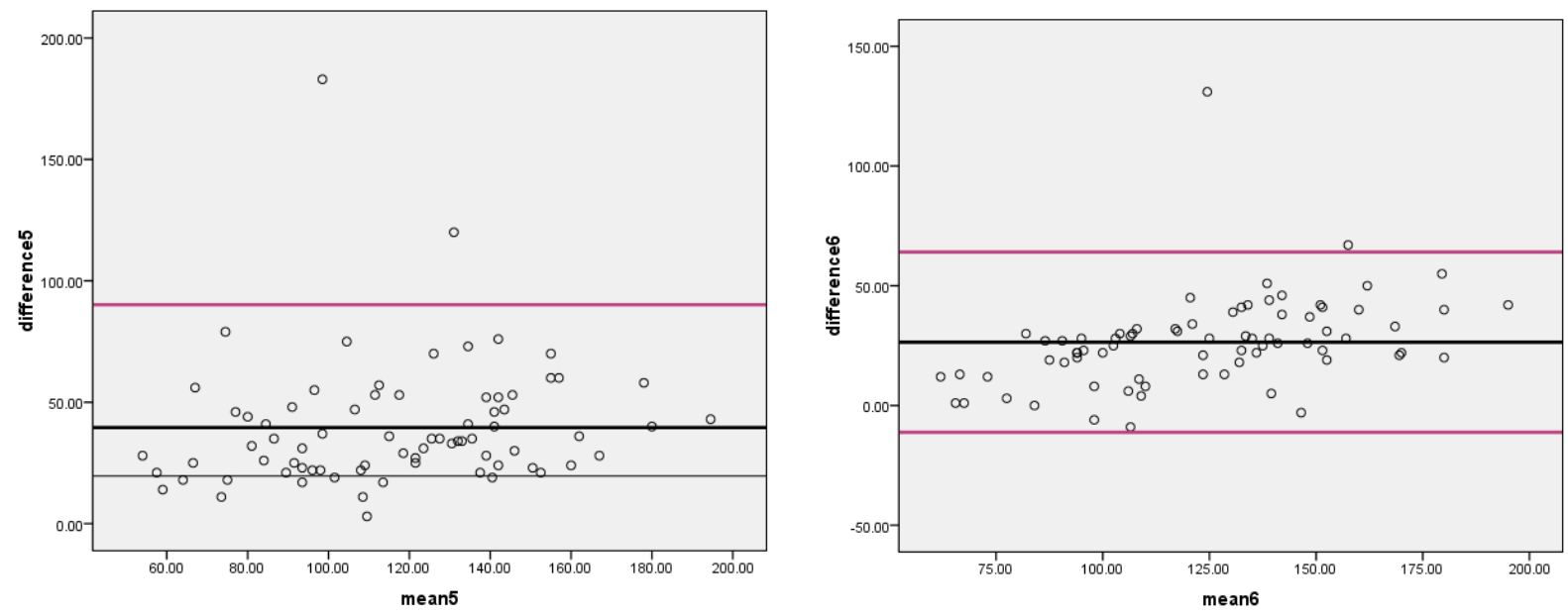

Gambar 1. Grafik Bland Altman Plot untuk Masing-Masing Selisih (Difference) dan Rerata (Mean) antara Kadar Kolesterol Direk dengan Kolesterol Hasil Hitung Formula \{Direk-

Friedelwald (1), Direk-Anandaraja (2), Direk-Puavilai (3), Direk-Chen (4), Direk-Vujovic (5), Direk-Cordova (6)

Tabel 3 menunjukkan bahwa kolesterol LDL hasil hitung formula yang memberikan selisih terkecil secara berurutan sampai terbesar adalah formula Chen, formula Cordova, formula Puavilai, formula Anandaraja, formula Friedewald, dan formula Vujovic. Berdasarkan grafik yang terlihat pada gambar 1, formula Friedewald dan Vujovic memiliki rentang batas kesesuaian yang sangat jauh bahkan batas bawahnya tidak terlihat pada grafik. Formula Anandaraja, Puavilai, Chen, dan Cordova sama-sama memiliki dua nilai diluar batas atas.

Terapi dislipidemia terutama berdasarkan pada kelainan kolesterol LDL. Hasil pemeriksaan kolesterol LDL harus dapat ditentukan dengan tepat agar dokter dapat menilai risiko seseorang mengalami penyakit penyempitan pembuluh darah akibat aterosklerosis. Jika kadar kolesterol LDL yang diperoleh lebih rendah daripada yang sebenarnya, maka dapat memperlambat dokter untuk memulai pengobatan terutama pada pasien dengan risiko tinggi. Sebaliknya, jika kadar kolesterol LDLyang diperoleh lebih tinggi daripada yang sebenarnya, akan menyebabkan pemberian terapi farmakologi yang tidak perlu. Pemeriksaan kadar LDL-Direk cukup mahal untuk dilakukan di tempat dengan fasilitas terbatas. Dalam beberapa dekade terakhir, sejumlah peneliti telah melakukan berbagai percobaan untuk mendapatkan formula perhitungan LDL yang lebih tepat dibandingkan formula yang telah umum digunakan yaitu formula Friedewald (Cholesterol \& Program, 2001.; Rim et al., 2016; Karkhaneh et al., 2019).

Hasil penelitian ini menunjukkan keenam formula LDL-Cal (Friedelwald, Chen, Anandaraja, Puavilai, Vujovic, dan Cordova) memberikan rerata hasil kolesterol LDL lebih rendah daripada LDL-Direk. Berdasarkan Bland Altman Plot, kolesterol LDL hasil hitung formula Chen memiliki kesesuaian paling baik, terlihat dari selisih rerata terkecil $(19,3867 \pm 19,0489 \mathrm{mg} / \mathrm{dl})$ dengan kolesterol LDL hasil pengukuran langsung. Hasil penelitian ini sesuai dengan penelitian yang dilakukan oleh Rim et al., (2016) di Seoul, Korea yang mendapatkan bahwa kolesterol LDL hasil hitung formula Chen memiliki selisih terkecil dibandingkan dengan ketiga formula lainnya yaitu formula Cordova, formula Anandaraja dan formula Friedewald. Martins et al., (2015) melakukan penelitian di Afrika Selatan dan menemukan bahwa kadar kolesterol LDL hasil hitung formula Chen dan Friedewald memiliki selisih lebih kecil dibandingkan formula Cordova. Hasil penelitian ini berbeda dengan penelitian yang dilakukan oleh Razi et al., (2017) 
pada penduduk Iran di Kota Tehran, yang menemukan bahwa hasil hitung formula yang memberikan selisih terkecil secara berurutan sampai terbesar dengan LDL direk adalah formula Friedewald, Chen, dan Anandraja.

Perbedaan hasil penelitian ini disebabkan karena beberapa hal diantaranya adanya perbedaan ras dan populasi serta perbedaan kondisi kesehatan antar subjek penelitian. Selain itu, penggunaan alat dan reagen yang berbeda untuk mengukur kadar lipid dapat mempengaruhi hasil. Variasi biologis seperti jenis kelamin dan usia juga mempengaruhi kadar lipid plasma yang disebabkan oleh perubahan kadar hormon seks (Rim et al., 2016; Karkhaneh et al., 2019;). Perbedaan ras dan populasi menyebabkan banyak peneliti dari berbagai negara berusaha menemukan formula baru yang paling tepat untuk populasinya masing-masing.

Penelitian ini memiliki sejumlah keterbatasan. Pertama, penelitian ini tidak menggunakan kuantifikasi beta/ $\beta$ yang merupakan metode baku emas untuk pengukuran kadar LDL karena berbagai keterbatasan yang ada. Kedua, sampel dalam penelitian ini memiliki kadar trigliserida tertinggi sebesar $347 \mathrm{mg} / \mathrm{dl}(<400 \mathrm{mg} / \mathrm{dl})$ sehingga hasil penelitian tidak dapat diterapkan pada pasien dengan hipertrigliseridemia. Ketiga, penelitian ini tidak membedakan sampel berdasarkan usia, jenis kelamin dan kondisi kesehatan.

\section{KESIMPULAN DAN SARAN}

Berdasarkan Bland Altman Plot, perhitungan kolesterol LDL dengan Formula Chen memiliki kesesuaian paling baik dengan LDL-Direk di RSUD Lubuk Sikaping pada kadar trigliserida < $400 \mathrm{mg} / \mathrm{dl}$. Penelitian selanjutnya diharapkan dapat menemukan formula baru yang paling tepat diterapkan pada pasien di RSUD Lubuk Sikaping termasuk pasien dengan hipertrigliseridemia.

\section{Ucapan Terima Kasih}

Penulis mengucapkan terima kasih kepada Kementerian Riset, Teknologi dan Pendidikan Tinggi serta LPPM Universitas Abdurrab yang telah mendukung terlaksananya penelitian ini.

\section{REFERENSI}

Cholesterol, N., \& Program, E. (n.d.). (2001). Third Report of the National Cholesterol Education Program (NCEP) Expert Panel on The National Cholesterol Education Program Expert Panel on Detection, Evaluation, and Treatment of High Blood Cholesterol in Adults (Adult Treatment Panel III). JAMA, 285: 2486-2497.

Dansethakul, P., Thapanathamchai, L., Saichanma, S., Worachartcheewan, A., \& Pidetcha, P. (2015). Determining a new formula for calculating low-density lipoprotein cholesterol: Data mining approach. EXCLI Journal, 14, 478-483.

Fawwad, A., Sabir, R., Riaz, M., \& Moin, H. (2016). Measured versus calculated LDLcholesterol in subjects with type 2 diabetes. Pakistan Journal of Medical Sciences, 32(4), 955-960.

Karkhaneh, A., Bagherieh, M., Sadeghi, S., \& Kheirollahi, A. (2019). Evaluation of eight formulas for LDL-C estimation in Iranian subjects with different metabolic health statuses. Lipids in Health and Disease, 18(1), 1-11.

Krishnaveni, P., \& Gowda, V. M. N. (2015). Assessing the validity of friedewald's formula and anandraja's formula for serum LDL-cholesterol calculation. Journal of Clinical and Diagnostic Research, 9(12), BC01-BC04.

Martin, S. S., Blaha, M. J., Elshazly, M. B., Brinton, E. A., Toth, P. P., McEvoy, J. W., et al. 
(2013). Friedewald-estimated versus directly measured low-density lipoprotein cholesterol and treatment implications. Journal of the American College of Cardiology, 62(8), 732739.

Martins, J., Olorunju, S. A. S., Murray, L. M., \& Pillay, T. S. (2015). Comparison of equations for the calculation of LDL-cholesterol in hospitalized patients. Clinica Chimica Acta, 444, 137-142.

Razi, F., Forouzanfar, K., Bandarian, F., \& Nasli-Esfahani, E. (2017). LDL-cholesterol measurement in diabetic type 2 patients: A comparison between direct assay and popular equations. Journal of Diabetes and Metabolic Disorders, 16(1), 1-5.

Rim, J. H., Lee, Y. H., Lee, M. H., Kim, H. Y., Choi, J., Lee, B. W., et al. (2016). Comparison and Validation of 10 Equations Including a Novel Method for Estimation of LDLcholesterol in a 168,212 Asian Population. Medicine (United States), 95(14), 1-8. 